Article

\title{
Age-Specific Excretion of Calcium, Oxalate, Citrate, and Glycosaminoglycans and Their Ratios in Healthy Children and Children with Urolithiasis
}

\author{
Daniel Turudic ${ }^{1, *}$, Anja Tea Golubic ${ }^{2}$, Mila Lovric ${ }^{3}$, Marko Bilic ${ }^{4}$ and Danko Milosevic ${ }^{5,6}$ \\ 1 Department of Pediatrics, University Hospital Centre Zagreb, 10000 Zagreb, Croatia \\ 2 Department of Nuclear Medicine and Radiation Protection, University Hospital Centre Zagreb, \\ 10000 Zagreb, Croatia; anja.tea.golubic@gmail.com \\ 3 Department of Laboratory Diagnostics, University Hospital Centre Zagreb, 10000 Zagreb, Croatia; \\ mlovric@kbc-zagreb.hr \\ 4 Department of Urology, University Hospital "Sveti Duh", 10000 Zagreb, Croatia; mbilic1407@gmail.com \\ 5 School of Medicine, University of Zagreb, 10000 Zagreb, Croatia; danko.milosevic@zg.t-com.hr \\ 6 General Hospital Zabok and Croatian Veterans Hospital, 49210 Zabok, Croatia \\ * Correspondence: danielturudic@gmail.com
}

\section{check for} updates

Citation: Turudic, D.; Golubic, A.T.; Lovric, M.; Bilic, M.; Milosevic, D. Age-Specific Excretion of Calcium, Oxalate, Citrate, and

Glycosaminoglycans and Their Ratios in Healthy Children and Children with Urolithiasis. Biomolecules 2021, 11,758. https://doi.org/10.3390/ biom 11050758

Academic Editors: Natalija Filipović and Katarina Vukojevic

Received: 7 April 2021

Accepted: 16 May 2021

Published: 19 May 2021

Publisher's Note: MDPI stays neutral with regard to jurisdictional claims in published maps and institutional affiliations.

Copyright: (C) 2021 by the authors. Licensee MDPI, Basel, Switzerland. This article is an open access article distributed under the terms and conditions of the Creative Commons Attribution (CC BY) license (https:/ / creativecommons.org/licenses/by/ $4.0 /)$.

\begin{abstract}
We analyzed children with urolithiasis with age- and gender-matched healthy children. Calcium ( $\mathrm{mmol} / \mathrm{mmol}$ creatinine) and the calcium/citrate ratio $(\mathrm{mol} / \mathrm{mmol})$ are the only variables that differentiate children before puberty from healthy children (ROC analysis confirmed only calcium/citrate as a significant variable with cut-off value $>0.84$ ). Peri-pubertal children are distinguished from age- and gender-matched healthy children by the following variables: citrate ( $\mathrm{mmol} / \mathrm{mol}$ creatinine), calcium/citrate $(\mathrm{mol} / \mathrm{mmol})$, oxalate/glycosaminoglycans (mmol/g), oxalate/citrate ratios $(\mathrm{mmol} / \mathrm{mmol})$ and oxalate $/$ (citrate $\times$ glycosaminoglycans) (mol oxalate $\times$ mol creatinine $) /($ mol citrate $\times$ g glycosaminoglycans). All variables were confirmed by ROC analysis with cut-off values $\leq 327.87,>1.02,>11.24,>0.12$ and $>0.03$, respectively. These results indicate a different risk of urinary stones development before puberty vs. pubertal/postpubertal children and increasing importance (deficiency) of citrate and glycosaminoglycans in such children. J48 classifier confirmed the importance of the oxalate/(citrate $\times$ glycosaminoglycans) and the calcium/citrate ratios (Ox/Cit $\times$ GAG 0.22 and Cit/GAG 0.612) with the practically applicable classification tree for distinguishing between pubertal/postpubertal children with urolithiasis with age- and gendermatched healthy children.
\end{abstract}

Keywords: calcium; oxalate; citrate; glycosaminoglycans; urolithiasis; children

\section{Introduction}

Ion interactions of urinary calcium (Ca), oxalate (Ox), and low urine citrate (Cit) may result in stone formation. Due to the strong affinity between $\mathrm{Ca}$ and $\mathrm{Ox}$ and the low calcium oxalate $(\mathrm{CaOx})$ solubility product, hypercalciuria and hyperoxaluria are the most common cause of renal stones. The excretion of urinary citrate (Cit), which forms a soluble compound with $\mathrm{Ca}$, reduces $\mathrm{CaOx}$ formation by depreciating the available $\mathrm{Ca}$ ions to interact with Ox [1-8]. Glycosaminoglycans (GAGs) (chondroitin sulfate, heparan sulfate, hyaluronic acid, dermatan sulfate, keratan sulfate) can also inhibit CaOx crystallization (this ability is attributed to at least the first three above) [1,9-20]. This study examines the relationship between urinary promoters/inhibitors and their ratios in children according to age. We consider GAGs' separation into its constituents costly and, for the current pupose, impractical for everyday clinical practice. 


\section{Materials and Methods}

\subsection{Urine Sampling and Analysis}

The study was conceived as an extension to our previous work of retrospective analysis of urinary stone disease in children from different parts of Croatia who had been treated for at least one urinary stone occurrence [20]. An ordinary abdominal X-ray (in selected cases, CT or MRI urography) and/or ultrasound were used for diagnosis. Children with glomerular diseases, urological anomalies, and coagulopathy were excluded from the study alongside hematuria of unknown origin. Children with acute urinary tract infections and metabolic abnormalities influencing urinary stone structure (i.e., children with hypercalciuria, hyperoxaluria, renal tubular acidosis, systemic metabolic diseases, hypokalemia, cystinuria, mucopolysaccharidoses) were excluded from the study too. Hypercalciuria was defined as urinary calcium excretion $>0.1 \mathrm{mmol} / \mathrm{kg} / 24 \mathrm{~h}$, primary hyperoxaluria as urinary oxalate excretion $>1 \mathrm{mmol} / 1.73 \mathrm{~m}^{2} / 24 \mathrm{~h}$ with glycolate excretion $>0.50 \mathrm{mmol} / 1.73 \mathrm{~m}^{2} / 24 \mathrm{~h}$ or L-glyceric acid excretion $>5 \mu \mathrm{mol} / \mathrm{L}$, idiopathic or mild hyperoxaluria as oxalate excretion $>0.50 \mathrm{mmol} / 1.73 \mathrm{~m}^{2} / 24 \mathrm{~h}$ with normal glycolate/L-glyceric acid excretion for both inherited and acquired disorders.

Primary hyperoxalurias (I, II, and III) and patients with possible nephrological metabolic/tubular disease were excluded by genetic testing [21-23]. Children with hypocitraturia (citrate excretion $<1.9 \mathrm{mmol} / 1.73 \mathrm{~m}^{2}$ for boys or $<1.6 \mathrm{mmol} / 1.73 \mathrm{~m}^{2}$ for girls) with genetic/metabolic causes were excluded as well [24]. Our aim was to avoid the influence of any major promoters/inhibitors and to determine the possible effect of GAGs on the origin of stone formation. Enteric hyperoxaluria-causing diseases (i.e., celiac disease, cystic fibrosis, children with steatorrhea) were clinically excluded. The largest number of stones was obtained by spontaneous stone passage followed by extracorporeal shock-wave lithotripsy (ESWL) or endoscopic removal procedure, respectively, rarely by open surgery. $\mathrm{CaOx}$ urolithiasis in children was confirmed by infrared spectroscopy, and only these children were enrolled in the study. Gender, age, and urinary excretion of Ca, Ox, Cit, and GAGs were used for the study. In total, 25 healthy gender- and age-matched children with informed parental consent served as a control group. All children were enrolled in the study with informed parents/guardians and older children's consent. For the urine samples to reflect a natural nutrient and fluid intake, the children were on a free diet. For the measurement of $\mathrm{Ca}, \mathrm{Ox}$, Cit and creatinine, 24-h urine collection was performed three days in a row. We used 24-h samples instead of 2-h morning or 12-h urine samples to acquire $\mathrm{Ca}, \mathrm{Ox}$, Cit, GAGs and creatinine excreted in urine as accurately as possible [25]. The intra-class correlation coefficient, built upon a trialed variable, was proven acceptable for further analysis (in the range of 0.79 to 0.93 ).

A wide-mouth plastic bottle encompasses $10 \mathrm{~mL}$ of $6 \mathrm{~N}$ hydrochloric acid (preservative) was used for Ox, Cit and corresponding creatinine urine collection. The 24-h urine samples without the addition of hydrochloric acid were used for measuring GAGs and corresponding creatinine (cr) in urine [26]. The Combur 9 test (Boehringer Mannheim, Germany) was used as a nitrite marker as well as urine culture to rule out urinary infection. Calcium was measured by the cresolphthalein-complexone method [26]. Dionex Series 4000i gradient ion chromatography was used for Ox and Cit measurement and carbazole method for GAGs determination. $\mathrm{Ca}, \mathrm{Ox}$, Cit, and all promoter/inhibitor values were calculated with respect to cr. Such a calculation ensures that the urine is collected correctly and correction of the values to the same indicator $[26,27]$.

Imprecision within batch for normal/high level (L1/L2) were for urine calcium from 0.51 to $0.56 \%$ and urine creatinine 0.45 to $1.15 \%$. Imprecisions between batches were for urine calcium $0.815-1.04 \%$ and urine creatinine $0.475-1.11 \%$. Accuracy determined by the recovery test for both levels was for calcium $98.5-103.5 \%$ and $98.4-103.5 \%$ for creatinine in urine. The method/analyte is included in the external proficiency testing scheme Instand.

Imprecision within batch for low / normal level (L1/L2) were for oxalate $2.45 / 0.42 \%$, citrate $4.89 / 0.65 \%$. Imprecision between the batch was for oxalate $7.01 / 5.51 \%$, citrate $9.64 / 5.29 \%$. Accuracy determined by the recovery test for all analytes was $98.5-103.5 \%$ for 
the normal level and $90.7-112.6 \%$ for low control levels. The method/analyte is included in the external proficiency testing scheme Reference Institute for Bioanalytics (Rfb).

\subsection{Data Analysis}

Urine excretion of $\mathrm{Ca}$ ( $\mathrm{mmol} / \mathrm{mmol}$ creatinine), $\mathrm{Ox}(\mathrm{mmol} / \mathrm{mol} \mathrm{cr}), \mathrm{Cit}(\mathrm{mmol} / \mathrm{mol} \mathrm{cr})$, GAGs (mg/mmol cr), Ca/Cit ( $\mathrm{mol} / \mathrm{mmol})$, Ox/GAGs (mmol/g), Ox/Cit ( $\mathrm{mmol} / \mathrm{mmol})$, $\mathrm{Ox} /(\mathrm{Cit} \times \mathrm{GAGs})(\mathrm{mol} \mathrm{Ox} \times \mathrm{mol} \mathrm{cr}) /(\mathrm{mol} \mathrm{Cit} \times \mathrm{g}$ GAGs$)$, and $\mathrm{Cit} / \mathrm{GAGs}(\mathrm{mmol} / \mathrm{g})$ were analyzed. Data are expressed as mean, standard deviation, median and interquartile range (IQR). The difference between subgroups was analyzed using the Mann-Whitney U-test [28]. Differences between multiple subgroups were analyzed using the KruskalWallis test with Bonferroni multiple comparison [28]. These tests were selected due to their insensitivity to outliers and extremes because of the considerable dispersion of trialed variable data. Therefore, outliers and extremes are included in our analysis instead of the previously allowed homogenizing data practice by removing data outside the interval defined as the mean \pm 2 standard deviations [29]. All applied tests were two-tailed, and $p$-values $\leq 0.05$ were acknowledged as statistically significant. Practical significances of selected variables were analyzed using ROC analysis. Data analysis was performed by using Statistica for Windows version 8 (StatSoft, Dell, Inc.) and GraphPad Prism version 5 GraphPad, San Diego, CA, USA). Additionally, the J48 classifier was used to construct a classification model for discrimination between subgroups [30-32]. J48 is a useful supplement to ROC analysis because of its reduced sensitivity to any imbalance in group size and the overall size of groups.

\section{Results}

The study includes 61 children with proven $\mathrm{CaOx}$ urolithiasis with a 59 single and 2 recurrent stone episode. Only children with idiopathic urolithiasis were included in the study. Approximately $1 / 3$ of the cases had a positive family history of urolithiasis. This group of children has compared with a group of 25 healthy children. Both groups are ageand gender-matched (gender differences; $\chi^{2}$-test, $p=0.906$ ). Children with urolithiasis and the control group of healthy children were compared by age, $\mathrm{Ca}$, Ox, Cit, GAGs, Ca/Cit, Ox/Cit, Ox/GAGs, Cit/GAGs and Ox/Cit $\times$ GAGs variables.

Groups of healthy children and children with urolithiasis were divided into subgroups according to age median criteria (expressed in months, mo.). Healthy children are therefore divided into 2 separate subgroups; a subgroup of younger children (YC) $(n=13)$ and a subgroup of older children (OC) $(n=12)$. Accordingly, children with urolithiasis also formed 2 subgroups, YC $(n=31)$ and OC $(n=30)$, using the median for healthy children. The age median of children was determined for individual YC and OC subgroups. Differences between healthy children vs. children with urolithiasis of both $Y C$ and OC subgroups are analyzed. $\mathrm{Ca}$ and $\mathrm{Ca} / \mathrm{Cit}$ are the only variables differentiating $\mathrm{YC}$ subgroups with significantly higher values for children with urolithiasis. OC subgroups had significantly higher values in healthy children for the Cit, $\mathrm{Ca} / \mathrm{Cit}$, Ox/GAG, Ox/Cit, Ox/(Cit × GAG) variables (Tables 1 and 2). 
Table 1. Descriptive statistics and Mann-Whitney U-test for YC with urolithiasis and matched control group of healthy children $(\mathrm{M}=$ male, $\mathrm{F}=$ female).

\begin{tabular}{|c|c|c|c|c|c|}
\hline \multirow[t]{3}{*}{$\begin{array}{l}\text { Total No. of } \\
\text { Children }\end{array}$} & \multicolumn{2}{|c|}{$\begin{array}{l}\text { Healthy Children } \\
\qquad(n=25)\end{array}$} & \multicolumn{2}{|c|}{$\begin{array}{l}\text { Children with Urolithiasis } \\
\qquad(n=61)\end{array}$} & \multirow{3}{*}{$p$ Value } \\
\hline & \multicolumn{2}{|c|}{$\begin{array}{l}\text { Healthy Children (YC) } \\
\qquad(n=13) \\
\mathrm{M}: \mathrm{F}=5: 8\end{array}$} & \multicolumn{2}{|c|}{$\begin{array}{c}\text { YC Children with Urolithiasis }(n=31), \mathrm{M}: \mathrm{F}=18: 13 \\
31 \text { Single Stone Occurrence, } 0 \text { Recurrent } \\
\text { Family History Positive (11 Total, 35.4\%) }\end{array}$} & \\
\hline & $\begin{array}{l}\text { Mean } \\
\text { (SD) }\end{array}$ & $\begin{array}{l}\text { Median } \\
\text { (IQR) }\end{array}$ & $\begin{array}{l}\text { Mean } \\
\text { (SD) }\end{array}$ & $\begin{array}{l}\text { Median } \\
\text { (IQR) }\end{array}$ & \\
\hline $\begin{array}{c}\text { Age } \\
\text { (months) }\end{array}$ & $\begin{array}{c}66.23 \\
(39.07)\end{array}$ & $\begin{array}{c}80.00 \\
(40.00 \text { to } 90.00)\end{array}$ & $\begin{array}{c}75.71 \\
(31.64)\end{array}$ & $\begin{array}{c}84.00 \\
(58.00 \text { to } 103.00)\end{array}$ & 0.3679 \\
\hline $\begin{array}{c}\mathrm{Ca} \\
(\mathrm{mmol} / \mathrm{mmol} \mathrm{cr})\end{array}$ & $\begin{array}{c}0.57 \\
(0.74)\end{array}$ & $\begin{array}{c}0.20 \\
(0.19 \text { to } 0.56)\end{array}$ & $\begin{array}{l}0.66 \\
(0.40)\end{array}$ & $\begin{array}{c}0.60 \\
(0.34 \text { to } 0.99)\end{array}$ & 0.0421 \\
\hline $\begin{array}{c}\mathrm{Ox} \\
(\mathrm{mmol} / \mathrm{mol} \mathrm{cr})\end{array}$ & $\begin{array}{l}111.58 \\
(84.02)\end{array}$ & $\begin{array}{c}79.21 \\
(64.40 \text { to } 122.20)\end{array}$ & $\begin{array}{c}72.44 \\
(49.07)\end{array}$ & $\begin{array}{c}62.63 \\
(43.00 \text { to } 84.74)\end{array}$ & 0.0971 \\
\hline $\begin{array}{c}\text { Cit } \\
(\mathrm{mmol} / \mathrm{mol} \mathrm{cr})\end{array}$ & $\begin{array}{c}438.49 \\
(279.36)\end{array}$ & $\begin{array}{c}368.10 \\
(337.00 \text { to } 408.80)\end{array}$ & $\begin{array}{c}391.36 \\
(232.55)\end{array}$ & $\begin{array}{c}380.42 \\
(219.00 \text { to } 507.20)\end{array}$ & 0.7674 \\
\hline $\begin{array}{c}\text { GAG } \\
(\mathrm{mg} / \mathrm{mmol} \mathrm{cr})\end{array}$ & $\begin{array}{l}5.40 \\
(3.60)\end{array}$ & $\begin{array}{c}4.25 \\
(3.93 \text { to } 5.40)\end{array}$ & $\begin{array}{c}4.80 \\
(3.78)\end{array}$ & $\begin{array}{c}3.54 \\
(2.15 \text { to } 6.20)\end{array}$ & 0.3347 \\
\hline $\mathrm{Ca} / \mathrm{Cit}$ & $\begin{array}{l}1.06 \\
(0.87) \\
\end{array}$ & $\begin{array}{c}0.84 \\
(0.94 \text { to } 1.39)\end{array}$ & $\begin{array}{c}4.54 \\
(12.18)\end{array}$ & $\begin{array}{c}1.60 \\
(0.97 \text { to } 3.27)\end{array}$ & 0.0140 \\
\hline Ox/GAG & $\begin{array}{c}25.63 \\
(22.36)\end{array}$ & $\begin{array}{c}18.64 \\
(14.21 \text { to } 22.95)\end{array}$ & $\begin{array}{l}22.35 \\
(15.09)\end{array}$ & $\begin{array}{c}22.20 \\
(10.13 \text { to } 39.76)\end{array}$ & 0.8672 \\
\hline $\mathrm{Ox} / \mathrm{Cit}$ & $\begin{array}{c}0.26 \\
(0.14)\end{array}$ & $\begin{array}{c}0.22 \\
(0.19 \text { to } 0.34)\end{array}$ & $\begin{array}{c}0.39 \\
(0.73)\end{array}$ & $\begin{array}{c}0.18 \\
(0.11 \text { to } 0.29)\end{array}$ & 0.2418 \\
\hline $\mathrm{Ox} /(\mathrm{Cit} \times \mathrm{GAG})$ & $\begin{array}{c}0.06 \\
(0.05)\end{array}$ & $\begin{array}{c}0.05 \\
(0.04 \text { to } 0.07)\end{array}$ & $\begin{array}{c}0.16 \\
(0.50) \\
\end{array}$ & $\begin{array}{c}0.05 \\
(0.03 \text { to } 0.10)\end{array}$ & 0.9692 \\
\hline Cit/GAG & $\begin{array}{l}109.93 \\
(99.32)\end{array}$ & $\begin{array}{c}85.18 \\
\text { (56.08 to } 95.34)\end{array}$ & $\begin{array}{c}127.62 \\
(120.39)\end{array}$ & $\begin{array}{c}84.66 \\
\text { (47.10 to } 160.47)\end{array}$ & 0.8269 \\
\hline $\begin{array}{c}\mathrm{Cr} \\
(\mathrm{mmol} / \text { day })\end{array}$ & $\begin{array}{c}3.30 \\
(1.80)\end{array}$ & $\begin{array}{c}3.86 \\
\text { (1.56 to } 4.96)\end{array}$ & $\begin{array}{c}4.31 \\
(2.42)\end{array}$ & $\begin{array}{c}3.90 \\
\text { (3.10 to } 5.02)\end{array}$ & 0.2687 \\
\hline
\end{tabular}

Table 2. Descriptive statistics and Mann-Whitney U-test for OC with urolithiasis and matched control group of healthy children $(\mathrm{M}=$ male, $\mathrm{F}=$ female).

\begin{tabular}{|c|c|c|c|c|c|}
\hline \multirow[t]{3}{*}{$\begin{array}{l}\text { Total No. of } \\
\text { Children }\end{array}$} & \multicolumn{2}{|c|}{$\begin{array}{l}\text { Healthy Children } \\
\qquad(n=25)\end{array}$} & \multicolumn{2}{|c|}{$\begin{array}{l}\text { Children with Urolithiasis } \\
\qquad(n=61)\end{array}$} & \multirow{3}{*}{$p$ Value } \\
\hline & \multicolumn{2}{|c|}{$\begin{array}{l}\text { Healthy Children (OC) } \\
\qquad(n=12) \\
\mathrm{M}: \mathrm{F}=6: 6\end{array}$} & \multicolumn{2}{|c|}{$\begin{array}{c}\text { OC Children with Urolithiasis }(n=30), \mathrm{M}: \mathrm{F}=22: 8 \\
28 \text { Single Stone Occurrence, } 2 \text { Recurrent } \\
\text { Family History Positive (11 Total, } 36.67 \%)\end{array}$} & \\
\hline & $\begin{array}{l}\text { Mean } \\
\text { (SD) }\end{array}$ & $\begin{array}{l}\text { Median } \\
\text { (IQR) }\end{array}$ & $\begin{array}{l}\text { Mean } \\
\text { (SD) }\end{array}$ & $\begin{array}{l}\text { Median } \\
\text { (IQR) }\end{array}$ & \\
\hline $\begin{array}{c}\text { Age } \\
\text { (months) }\end{array}$ & $\begin{array}{l}142.67 \\
(26.31)\end{array}$ & $\begin{array}{c}134.50 \\
(122.50 \text { to } 157.00)\end{array}$ & $\begin{array}{l}157.13 \\
(25.49)\end{array}$ & $\begin{array}{c}158.50 \\
(133.00 \text { to } 176.00)\end{array}$ & 0.0818 \\
\hline $\begin{array}{c}\mathrm{Ca} \\
(\mathrm{mmol} / \mathrm{mmol} \mathrm{cr})\end{array}$ & $\begin{array}{c}0.34 \\
(0.17)\end{array}$ & $\begin{array}{c}0.36 \\
(0.19 \text { to } 0.49)\end{array}$ & $\begin{array}{c}0.46 \\
(0.47)\end{array}$ & $\begin{array}{c}0.33 \\
(0.25 \text { to } 0.59)\end{array}$ & 0.6065 \\
\hline $\begin{array}{c}\mathrm{Ox} \\
(\mathrm{mmol} / \mathrm{mol} \mathrm{cr})\end{array}$ & $\begin{array}{c}44.94 \\
(21.60)\end{array}$ & $\begin{array}{c}44.15 \\
\text { (27.15 to } 56.32)\end{array}$ & $\begin{array}{c}67.52 \\
(43.91)\end{array}$ & $\begin{array}{c}53.54 \\
(34.81 \text { to } 86.74)\end{array}$ & 0.1157 \\
\hline $\begin{array}{c}\text { Cit } \\
(\mathrm{mmol} / \mathrm{mol} \mathrm{cr})\end{array}$ & $\begin{array}{c}363.89 \\
(152.65)\end{array}$ & $\begin{array}{c}361.71 \\
\text { (276.74 to } 414.08)\end{array}$ & $\begin{array}{c}261.59 \\
(184.41)\end{array}$ & $\begin{array}{c}239.61 \\
(126.89 \text { to } 321.12)\end{array}$ & 0.0154 \\
\hline
\end{tabular}


Table 2. Cont.

\begin{tabular}{|c|c|c|c|c|c|}
\hline \multirow[t]{3}{*}{$\begin{array}{l}\text { Total No. of } \\
\text { Children }\end{array}$} & \multicolumn{2}{|c|}{$\begin{array}{l}\text { Healthy Children } \\
\qquad(n=25)\end{array}$} & \multicolumn{2}{|c|}{$\begin{array}{l}\text { Children with Urolithiasis } \\
\qquad(n=61)\end{array}$} & \multirow{3}{*}{$p$ Value } \\
\hline & \multicolumn{2}{|c|}{$\begin{array}{l}\text { Healthy Children (OC) } \\
\qquad \begin{array}{l}(n=12) \\
\mathrm{M}: \mathrm{F}=6: 6\end{array}\end{array}$} & \multicolumn{2}{|c|}{$\begin{array}{c}\text { OC Children with Urolithiasis }(n=30), \mathrm{M}: \mathrm{F}=22: 8 \\
28 \text { Single Stone Occurrence, } 2 \text { Recurrent } \\
\text { Family History Positive (11 Total, 36.67\%) }\end{array}$} & \\
\hline & $\begin{array}{l}\text { Mean } \\
\text { (SD) }\end{array}$ & $\begin{array}{l}\text { Median } \\
\text { (IQR) }\end{array}$ & $\begin{array}{l}\text { Mean } \\
\text { (SD) }\end{array}$ & $\begin{array}{l}\text { Median } \\
\text { (IQR) }\end{array}$ & \\
\hline $\begin{array}{c}\text { GAG } \\
(\mathrm{mg} / \mathrm{mmol} \mathrm{cr})\end{array}$ & $\begin{array}{l}3.66 \\
(2.38)\end{array}$ & $\begin{array}{c}3.54 \\
(1.51 \text { to } 4.82)\end{array}$ & $\begin{array}{c}2.42 \\
(1.93)\end{array}$ & $\begin{array}{c}1.78 \\
(1.24 \text { to } 3.00)\end{array}$ & 0.0794 \\
\hline $\mathrm{Ca} / \mathrm{Cit}$ & $\begin{array}{l}1.06 \\
(0.77)\end{array}$ & $\begin{array}{c}0.85 \\
(0.54 \text { to } 1.41)\end{array}$ & $\begin{array}{c}2.26 \\
(2.01)\end{array}$ & $\begin{array}{c}1.50 \\
(1.10 \text { to } 2.63)\end{array}$ & 0.0113 \\
\hline $\mathrm{Ox} / \mathrm{GAG}$ & $\begin{array}{c}22.23 \\
(35.33)\end{array}$ & $\begin{array}{c}10.46 \\
(7.00 \text { to } 31.34)\end{array}$ & $\begin{array}{c}39.47 \\
(37.50)\end{array}$ & $\begin{array}{c}27.74 \\
(16.09 \text { to } 44.07)\end{array}$ & 0.0278 \\
\hline Ox/Cit & $\begin{array}{c}0.14 \\
(0.09)\end{array}$ & $\begin{array}{c}0.11 \\
(0.09 \text { to } 0.18)\end{array}$ & $\begin{array}{c}0.39 \\
(0.46)\end{array}$ & $\begin{array}{c}0.25 \\
(0.14 \text { to } 0.46)\end{array}$ & 0.0113 \\
\hline $\mathrm{Ox} /(\mathrm{Cit} \times \mathrm{GAG})$ & $\begin{array}{c}0.08 \\
(0.09)\end{array}$ & $\begin{array}{c}0.02 \\
(0.02 \text { to } 0.14)\end{array}$ & $\begin{array}{c}0.24 \\
(0.29)\end{array}$ & $\begin{array}{c}0.11 \\
(0.05 \text { to } 0.30)\end{array}$ & 0.0058 \\
\hline Cit/GAG & $\begin{array}{l}136.61 \\
(89.87)\end{array}$ & $\begin{array}{c}98.55 \\
(82.35 \text { to } 191.29)\end{array}$ & $\begin{array}{c}152.32 \\
(110.21)\end{array}$ & $\begin{array}{c}133.04 \\
(66.36 \text { to } 209.49)\end{array}$ & 0.8237 \\
\hline $\begin{array}{c}\mathrm{Cr} \\
(\mathrm{mmol} / \text { day })\end{array}$ & $\begin{array}{c}8.10 \\
(3.28)\end{array}$ & $\begin{array}{c}7.85 \\
\text { (5.96 to } 10.60)\end{array}$ & $\begin{array}{c}8.14 \\
(4.30)\end{array}$ & $\begin{array}{c}7.27 \\
\text { (5.56 to } 10.30)\end{array}$ & 0.8021 \\
\hline
\end{tabular}

Clinical staging of puberty was not a part of this study from the beginning of study. However, as we found possible gender differences between subgroups, these were tested by the Kruskal-Wallis test and Bonferroni multiple comparisons. A significant difference was found for $\mathrm{Ca}$ and Cit between female YC vs. OC male groups $(p=0.008)$. These differences were further tested by post-hoc Mann-Whitney U test with our children's median values for gender (female 109 mo. and 127 mo. for male children). We found significant differences in the variables mentioned above regarding excretion of $\mathrm{Ca}$ (female YC vs. male OC and male YC vs. male OC). Significant differences were found also for Cit excretion (female YC vs. male OC, female YC vs. female OC and male YC vs. male OC (Figure 1). Excretion of Ox was not statistically significant.

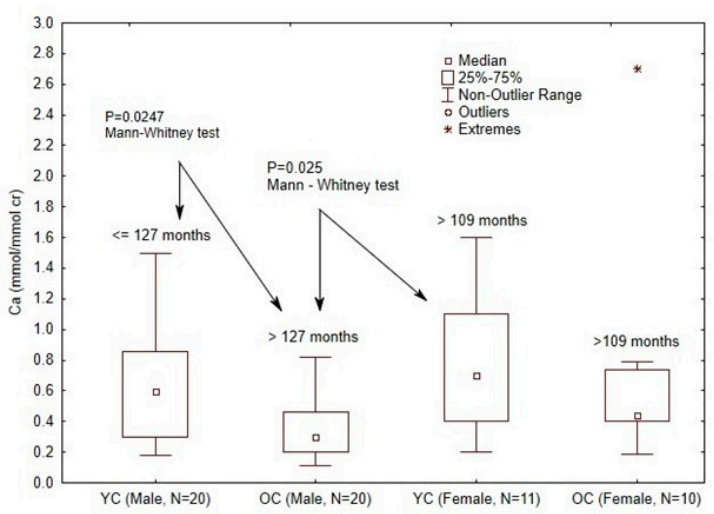

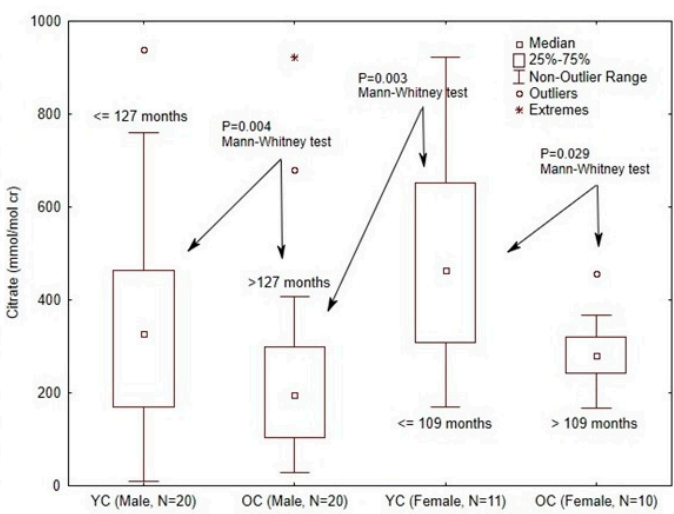

Figure 1. Possible gender differences between subgroups were tested by the Kruskal-Wallis test and Bonferroni multiple comparisons. Differences between female YC vs. OC male groups ( $p=0.008)$ were further test by post-hoc Mann-Whitney $\mathrm{U}$ test in accordance with cut-off values to our gender median (female $109 \mathrm{mo}$. and male 127 mo.). Significant differences were found for $\mathrm{Ca}$ (female YC vs. male OC and male YC vs. male OC) in section (A) and Cit excretion (female YC vs. male OC, female YC vs. female OC, and male YC vs. male OC) in section (B). 
Our group of children was carefully selected to fully express promoter/inhibitor ratios and GAGs in adherence with inclusion/exclusion criteria. Therefore, they represent a relatively homogenized group by excluding all potent and already known promoters. The resulting cohort of children has no prominent stone-forming predictors. The drawback of such criteria are relatively small groups with limited possibility to form firm conclusions.

Therefore, the above-listed variables of children were analyzed using ROC analysis. Judging by their AUC and $p$-values that fit potential diagnostic abilities, variables are listed according to their $p$-values. The results of ROC analysis for statistically significant variables are shown in Table 3. Statistically significant differences were found between healthy children vs. children with urolithiasis for Cit, Ca/Cit, Ox/GAG, Ox/Cit and $\mathrm{Ox} / \mathrm{Cit} \times$ GAGs variables. Distinctive sensitivity with low specificity was found for all examined variables. A significant difference with high sensitivity was found in $\mathrm{YC}$ only for the $\mathrm{Ca} / \mathrm{Cit}$ variable. OC show moderate/high sensitivity for $\mathrm{Cit}, \mathrm{Ca} / \mathrm{Cit}$, Ox/GAG, $\mathrm{Ox} / \mathrm{Cit}$ and $\mathrm{Ox} / \mathrm{Cit} \times \mathrm{GAGs}$ variables but with low to moderate specificity. All variables have a significant number of outliers and extremes. A Cit variable was found low in OC with urolithiasis vs. healthy children. At the same time, $\mathrm{Ca} / \mathrm{Cit}$, Ox/Cit and GAGs ratios (Ox/GAGs and Ox/Cit $\times$ GAGs) were significantly higher in $\mathrm{OC}$ with urolithiasis. Differences found in $\mathrm{Ca}, \mathrm{Ox}$, Cit and GAGs excretion in healthy children vs. children with urolithiasis were useful for estimation of Cit, Ox and GAGs post-puberty changes.

Table 3. Summary of ROC analysis for statistically significant variables.

\begin{tabular}{|c|c|c|c|c|c|}
\hline \multicolumn{6}{|c|}{ Healthy YC Children $(n=13)$ vs. YC with Urolithiasis $(n=31)$} \\
\hline Variables & Cut-off value & AUC & Sensitivity & Specificity & $p$-value \\
\hline $\mathrm{Ca} / \mathrm{Cit}$ & $>0.84$ & $\begin{array}{c}0.737 \\
(0.571 \text { to } 0.903)\end{array}$ & 83.87 & 53.85 & 0.0050 \\
\hline \multicolumn{6}{|c|}{ Healthy OC Children $(n=12)$ vs. OC with Urolithiasis $(n=30)$} \\
\hline Variables & Cut-off value & AUC & Sensitivity & Specificity & $p$-value \\
\hline Cit $(\mathrm{mmol} / \mathrm{mol} \mathrm{cr})$ & $\leq 327.87$ & $\begin{array}{c}0.742 \\
(0.578 \text { to } 0.906)\end{array}$ & 80.00 & 66.67 & 0.0039 \\
\hline $\mathrm{Ca} / \mathrm{Cit}$ & $>1.02$ & $\begin{array}{c}0.753 \\
(0.585 \text { to } 0.921)\end{array}$ & 76.67 & 66.67 & 0.0032 \\
\hline Ox/GAG & $>11.24$ & $\begin{array}{c}0.719 \\
(0.515 \text { to } 0.924)\end{array}$ & 86.67 & 66.67 & 0.0355 \\
\hline Ox/Citrate & $>0.12$ & $\begin{array}{c}0.753 \\
(0.601 \text { to } 0.904)\end{array}$ & 80.00 & 75.00 & 0.0011 \\
\hline $\mathrm{Ox} /(\mathrm{Cit} \times \mathrm{GAG})$ & $>0.03$ & $\begin{array}{c}0.775 \\
(0.600 \text { to } 0.950)\end{array}$ & 93.33 & 58.33 & 0.0021 \\
\hline
\end{tabular}

Some children due to their metabolic urinary values belong to the outliers/extremes. Urinary analysis, performed 3 times, revealed mild hyperoxaluria in two children marked as extremes as well as two children with hypocitraturia. The same applies to one child with the lowest oxalate $/>0.1 \mathrm{mmol} / \mathrm{kg}$ value $x$ ratio of GAG (outlier) who has a GAG significantly below the values of healthy children.

To optimally classify healthy children vs. children with urolithiasis J48 classifier was applied (Figure 2). Only healthy OC vs. OC with urolithiasis are successfully classified. $\mathrm{J} 48$ classifier uses $\mathrm{Ox} / \mathrm{Cit} \times \mathrm{GAG}$ and $\mathrm{Ca} / \mathrm{Cit}$ ratios to discriminate between $\mathrm{OC}$ with urolithiasis from OC healthy children. The classification tree has two decision nodes and three decision leaves (Figure 2 and Table 4). 
Table 4. The performance measures for classification tree (confusion matrix).

\begin{tabular}{clc}
\hline Class & \multicolumn{2}{c}{ J48 Classification } \\
\hline Healthy children $(n=12)$ & Healthy children $(n=9)$ & Urolithiasis $(n=3)$ \\
Urolithiasis $(n=30)$ & Healthy children $(n=1)$ & Urolithiasis $(n=29)$ \\
\hline
\end{tabular}

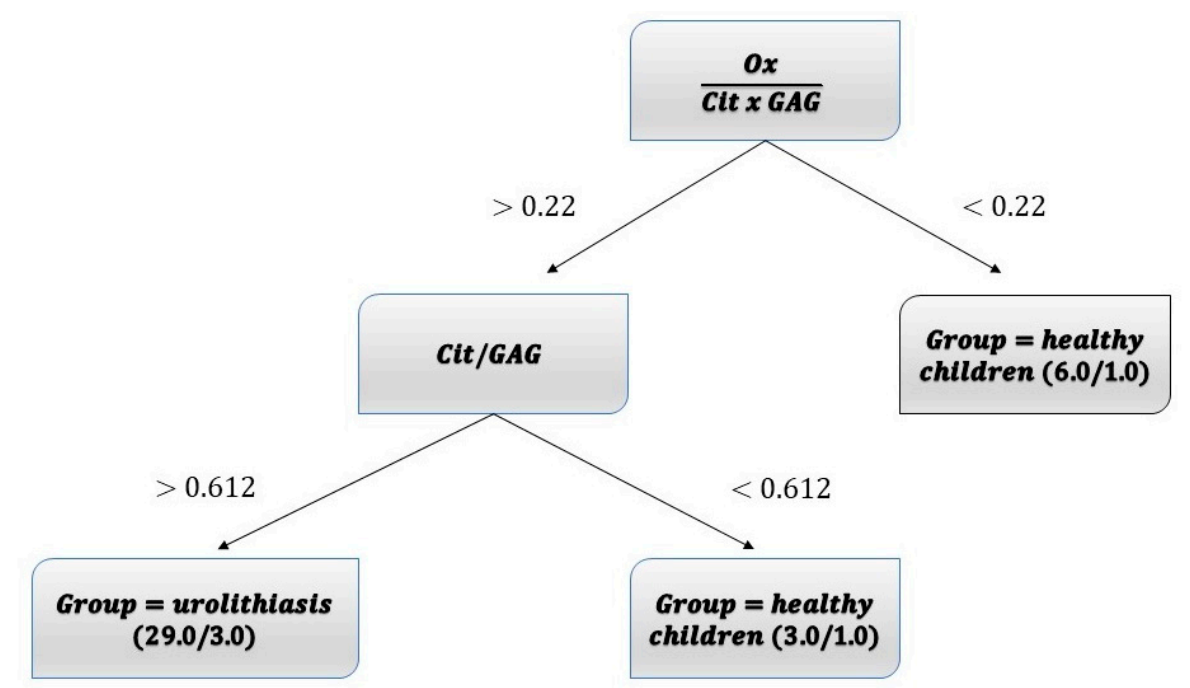

Figure 2. Classification tree for discrimination between OC healthy children and children with urolithiasis. The classification tree has two decision nodes and three decision leaves (for clarity, all variables are designated by full names instead by abbreviations, except for glycosaminoglycans (GAG).

DECISION NODE 1

IF Ox $/($ Cit $\times$ GAG) ratio $<0.22$ THEN group = healthy children (precision 6.0/1.0)

ELSE IF Ox(Cit $\times$ GAG) ratio $\geq 0.22$ THEN DECISION NODE 2

\section{DECISION NODE 2}

IF Ca/Cit ratio $<0.612$ THEN group = healthy children (precision 3.0/1.0)

ELSE IF Ca/Cit ratio $\geq 0.612$ THEN group = urolithiasis (precision 29.0/3.0)

The number of correctly classified children is 38 of 42 , i.e., $90.8 \%$, with Kappa statistics of 0.754 (Table 4 )

\section{Discussion}

Children develop physically and mentally over time. This is a period marked with numerous changes in the endocrine and metabolic regulations, of which puberty is one of the most important. We, therefore, decided to evaluate the median age as a distinguishing factor, primarily because it may coincide with peri-puberty in children. The possibility of changing interrelation of $\mathrm{Ca}$, Ox, Cit and GAGs excretion during the peri-pubertal period motivated us to investigate the possible changing risk of urolithiasis in this developmental period. We divided the study children into young and older groups in order to investigate the changing risk of urolithiasis during this period. Cut-off values for the timing of puberty (female $125 \mathrm{mo}$. and male $133 \mathrm{mo}$.) were considered as referral values [33]. We believe that a differences found in $\mathrm{Ca}$ and Cit between female $\mathrm{YC}$ vs. OC male groups as well as for Cit female YC vs. OC and male YC vs. OC indicating peri-pubertal changes. It is likely that peri-pubertal changes account for the observed differences in the profiles for calcium, citrate and GAG excretion of young and older children

Studies analyzing urinary promoter/inhibitor variables such as $\mathrm{Ca}, \mathrm{Ox}$, Cit and their ratios in children are uncommon in literature. Since $\mathrm{Ca}$ is a strong promoter of urolithiasis with possible masking influences over the other promoters/inhibitors, we assumed that previous researchers' negative results of GAGs excretion in children's urine 
with urolithiasis might be partly due to the inclusion of participants with prominent metabolic promoters (hypercalciuria included) [16,26]. Previous researchers of Ox, Cit and GAGs interactions frequently opted for Ca exclusion [10,11]. We also found Ca excretion in urine as an important contributor to urinary stone development in children with urolithiasis, significantly higher in female YC vs. male OC. A higher Ca excretion was found in $\mathrm{YC}$ in comparison with corresponding male OC. At the same time, the $\mathrm{Ca} / \mathrm{Cit}$ ratio shows substantial differences in all children, $\mathrm{YC}$ and $\mathrm{OC}$ alike, between healthy children and children with urolithiasis. Even though $\mathrm{Ca}$ excretion was moderately significant $(p<0.05)$ only in YC (not confirmed by ROC analysis), we can assume that increased urinary $\mathrm{Ca}$ excretion with the given excretion of $\mathrm{Cit}$ is the most plausible explanation for the higher risk of stone formation in $\mathrm{YC}$ with urolithiasis. Therefore, in the young children, the raised $\mathrm{Ca} / \mathrm{Cit}$ and increased risk for stones was due to increased $\mathrm{Ca}$ excretion and not to a decrease in Cit.

Figure 1 clearly shows that the ratios of $\mathrm{Ca} / \mathrm{cr}$ and $\mathrm{Cit} / \mathrm{cr}$ were significantly higher in young boys compared with older boys, and similarly for girls. This is probably largely attributable to use of creatinine as denominator in the calculation. In healthy children there is a progressive linear increase in creatinine excretion from low values in early life to peak in late adolescence which is due to increasing skeletal muscle. There is little difference between sexes in young children, but there is divergence from puberty with higher creatinine excretion in boys [34,35].

Urinary oxalate excretions were previously investigated in Croatia in children with genetic diseases (primary hyperoxalurias I, II, III) [26,27,36,37]. As high oxalate in urine decreases the inhibitory effectiveness and protection from crystallization, we opted for primary hyperoxalurias exclusion from all calculations [13].

The age difference in stone risk formation and a decrease in Cit excretion was previously described in the literature $[6,38,39]$. It has already been reported that besides hypercalciuria, hypocitraturia is the most common association with urolithiasis [3-8]. We observed a decrease in Cit excretion of healthy male and female OC, with higher Cit reduction in males in comparison with females, both indicating postpuberty Cit excretion decrease. The highest fall of Cit excretion was found between female YC vs. male OC. Lower Cit excretion in OC is the main cause for higher values of Ox/Cit and Ox/Cit $\times$ GAGs ratios in children with urolithiasis. The importance of urine Cit excretion is shown in the decision tree model using the $\mathrm{Ca} / \mathrm{Cit}$ ratio as the second decision node in OC. Interaction of inhibition of the NaDC-1 citrate transporter by the oxalate transporter slc26a6 in the absence of hypercalciuria and/or calcium sensor receptor alteration may be an answer to the question of whether stone-free or stone-recurrence in OC will occur and explain some of our outliers and extremes [40-42].

Articles detailing macromolecules, such as the excretion of GAGs and their urine ratios, are exceedingly rare. A definitive conclusion of their interactions (depletion) with other promoters/inhibitors of crystallization is still not possible to define. An increase of GAGs excretion in infants was previously observed [2]. As promoter/inhibitor ratios (Ox/GAGs and Ox/Cit $\times$ GAGs) isolate stone-forming OC and healthy group, the only plausible explanation is influence of GAGs on stone formation in infants. Therefore, due to a lower GAGs urine excretion in OC, Ox/GAGs and Ox/Cit $\times$ GAG ratios are higher in children with urolithiasis compared with healthy children. Ox/Cit $\times$ GAG ratio combined with $\mathrm{Ca} / \mathrm{Cit}$ ratio distinguishes OC children with urolithiasis from healthy children at the first decision node. Statistical significant $\mathrm{Ox} / \mathrm{Cit} \times \mathrm{GAG}$ ratio in $\mathrm{OC}$ indicates a decrease in GAG excretion of postpubertal children. Although we excluded all known genetic and metabolic diseases, there is a possibility of yet undiscovered genetic and metabolic disruptors in our stone formers. The model to pinpoint candidate(s) for unknown genetic mutations and diseases, is to search for outliers and extremes in a meticulously controlled study. In our stone formers, there are some possible candidates for such diseases. They include children with mild hyperoxaluria and oxalate excretion between $>500$ and $<1000 \mu \mathrm{mol} / 1.73 \mathrm{~m}^{2} / 24-\mathrm{h}$ body weight of yet unknown origin, children with hypoci- 
traturia and a child with urinary GAGs considerably lower than normal children. Most outliers and extremes have all three components of Ox/Cit $\times$ GAG ratio close to upper (oxalate) or lower (citrate and GAGs) normal limits.

Lithogenic protection in children's urine is higher compared with adults due to a higher excretion of macromolecules, including increased excretion of Cit, GAG and fibronectin $[2,4,43,44]$. Elevated GAGs excretion in infants and toddlers' urine is explained by increased excretion of proteoglycans in longitudinally growing bones [43]. This protective role of GAGs is consistent with observation for the lowest incidence of urinary stone formation in children 0-3 years [45]. Articles describing excretion of GAGs in urine are scarce and with no clear consensus [16,42-44,46]. Reduced excretion of GAGs' in urine is rarely reported in children $[15,42,44,46]$. Although some constituents of GAGs have an inhibitory role, others could even promote $\mathrm{CaOx}$ crystallization $[17,42,46]$. The protective part of GAGs depends on their degree of sulfation, i.e., the number of anionic charged sites on the surface $[14,17,47]$. This protection is also achieved by inhibition of $\mathrm{CaOx}$ monohydrate crystal adherence to renal epithelial cells by GAGs $[9,18,19,47]$. GAGs constituents (chondroitin sulfate and heparan sulfate) may act as a polymer with an aggregative effect, promoting small crystal forming but inhibiting grand crystal growth [42,46,47]. Increased GAGs production induced by tubular injury in the presence of $\mathrm{CaOx}$ crystals and Ox ions is well documented, as well as GAGs' role in reducing renal tubular cell injury caused by crystals and their oxidative stress-induced apoptosis $[2,9,14,44]$. The fact that GAGs depletion in urine is found in some studies and by other unaltered, compared to healthy subjects, may reflect GAGs' adequate or inadequate activity to suppress tubular injury when the samples were actually taken for analysis $[15,16]$. Therefore, research of urinary stone formation overseen immediately or after a considerable time since acute stone episode may contribute to different results. Pathological values of urinary GAGs in stone disease of children are undefined, as is the possibility of mutation leading to urine GAG depletion $[4,46]$. To our knowledge, any attempt to identify GAG's only defect in urinary stone disease has not yet succeeded.

GAGs are better expressed, and their inhibitory potential is evaluated as part of ratios with Ox and Cit [10-12]. In Ox/Cit $\times$ GAG ratio, we assessed urinary Ox known to have the stone promoting capability as a counter with two inhibitors as denominators [26,27]. We noticed that all three ratio components could be within normal ranges, and still, the outcome of the ratio reaches end-cumulative pathological values. The result may get significant differences for stone formers in comparison to healthy children. Amplifying minor differences in urine composition of this ratio's components was already observed $[10,26,27]$. Low urinary Cit and consequential GAGs depletion can explain the positive result of $\mathrm{Ox} / \mathrm{Cit}$, Ox/GAG andOx/Cit $\times$ GAGs ratio. Some ratio disturbances can be corrected because Cit intake increases GAG excretion in the urine, but the opposite vice versa can also be assumed [1]. The constant decline in Cit and GAG values during aging in OC can affect the stone's promotion more than previously expected. It remains to be determined whether this shift in promoter/inhibitor disturbance is due to some peri-puberty hormonal changes. The post-pubertal excretion values of Ox, Cit and GAG in OC appear to match the risk of adult urinary stones better. Therefore, in absence of hypercalciuria and primary hyperoxalurias in OC a cumulative effect of Ox, Cit and GAGs disturbance(s) with relatively slow growth of urinary stone is assumed, probably similar to stone genesis in adults.

Author Contributions: Conceptualization, D.T. and D.M.; methodology, D.M.; software, M.B.; validation, A.T.G., D.T., D.M. and M.L.; formal analysis, D.M. and M.L.; investigation, A.T.G.; data curation, A.T.G. and M.L.; writing-original draft preparation, D.T.; writing-review and editing, D.M.; visualization, D.T.; supervision, D.M.; project administration, D.M. All authors have read and agreed to the published version of the manuscript.

Funding: This research received no external funding. 
Institutional Review Board Statement: The study was conducted according to the guidelines of the Declaration of Helsinki, and approved by the Ethics Committee of the University Hospital Centre Zagreb.

Informed Consent Statement: Informed consent was obtained from all subjects involved in the study. Written informed consent has been obtained from the patient(s) to publish this paper.

Conflicts of Interest: The authors declare no conflict of interest.

\section{References}

1. Shang, Y.F.; Xu, M.; Zhang, G.N.; Ouyang, J.M. Concave urinary cristallines: Direct evidence of calcium oxalate crystals dissolution by citrate in vivo. Bioinorg. Chem. Appl. 2013, 2013, 637617. [CrossRef] [PubMed]

2. Miyake, O.; Kakimoto, K.; Tsujihata, M.; Yoshimura, K.; Takahara, S.; Okuyama, A. Strong inhibition of crystall-cell attachment by pediatric urinary macromolecules: A close relationship with urinary citrate secretion. Urology 2001, 58, 493-497. [CrossRef]

3. DeFoor, W.R.; Jackson, E.; Minevich, E.; Caillat, A.; Reddy, P.; Sheldon, C.; Asplin, J. The risk of recurrent urolithiasis in children is dependent on urinary calcium and citrate. Urology 2010, 76, 242-245. [CrossRef] [PubMed]

4. Domrongkitchaiporn, S.; Stitchantracul, W.; Kochakarn, W. Causes of hypocitraturia in recurrent calcium stone formers: Focusing on urinary potassium excretion. Am. J. Kidney Dis. 2006, 48, 546-554. [CrossRef]

5. Kovacevic, L.; Wolfe-Christensen, C.; Edwards, L.; Sadaps, M.; Lakshmanan, Y. From hypercalciuria to hypocitraturia-A shifting trend in pediatric urolithiasis? J. Urol. 2012, 188 (Suppl. S4), 1623-1627. [CrossRef]

6. Tefekli, A.; Esen, T.; Ziylan, O.; Erol, B.; Armagan, A.; Ander, H.; Akinci, M. Metabolic risk factors in pediatric and adult calcium oxalate urinary stone formers: Is there any difference? Urol. Int. 2003, 70, 273-277. [CrossRef] [PubMed]

7. VanDervoort, K.; Wiesen, J.; Frank, R.; Vento, S.; Crosby, V.; Chandra, M.; Trachtman, H. Urolithiasis in pediatric patients: A single center study of incidence, clinical presentation and outcome. J. Urol. 2007, 177, 2300-2305. [CrossRef]

8. Strohmaier, W.L.; Seilnacht, J.; Schubert, G. Urinary stone formers with hypocitraturia and "normal" urinary pH at high risk for recurrence. Urol. Int. 2012, 88, 294-297. [CrossRef] [PubMed]

9. Ebisuno, S.; Kohjimoto, Y.; Tamura, M.; Ohkawa, T. Adhesion of calcium oxalate crystals to Madin-Darby canine kidney cells and some effects of glycosaminoglycans or cell injuries. Eur. Urol. 1995, 28, 68-73. [CrossRef] [PubMed]

10. Baggio, B.; Gambaro, G.; Oliva, O.; Favaro, S.; Borsatti, A. Calcium oxalate nephrolithiasis: An easy way to detect an imbalance between promoting and inhibiting factors. Clin. Chim. Acta 1982, 124, 149-155. [CrossRef]

11. Baggio, B.; Gambaro, G.; Favaro, S.; Borsatti, A.; Pavanello, L.; Siviero, B.; Zacchello, G.; Rizzoni, G.F. Juvenile renal stone disease: A study of urinary promoting and inhibiting factors. J. Urol. 1983, 130, 1133-1135. [CrossRef]

12. Batinic, D.; Milosevic, D.; Konjevoda, P.; Nizic, L.J.; Vrljicak, K.; Matkovic, M.; Batinic, D.; Grkovic, L. The value of urine citrate/calcium ratio in the estimation of risk of urolithiasis. Clin. Nephrol. 2004, 61, 387-391. [CrossRef] [PubMed]

13. Cao, L.C.; Deng, G.; Boevé, E.R.; Romijn, J.C.; de Bruijn, W.C.; Verkoelen, C.F.; Schröder, F.H. Does urinary oxalate interfere with the inhibitory role of glycosaminoglycans and semisynthetic sulfated polysaccharides in calcium oxalate crystallization? Eur. Urol. 1997, 31, 485-492. [CrossRef]

14. Borges, F.T.; Michelacci, Y.M.; Aguiar, J.A.K.; Dalboni, M.A.; Garofalo, A.S.; Schor, N. Characterization of glycosaminoglycans in tubular epithelial cells: Calcium oxalate and oxalate ions effects. Kidney Int. 2005, 68, 1630-1642. [CrossRef] [PubMed]

15. Akcay, T.; Konukoglu, D.; Dincer, Y. Urinary glycosaminoglycan excretion in urolithiasis. Arch. Dis. Child. 1999, 80, $271-272$. [CrossRef] [PubMed]

16. Harangi, F.; Gyorke, Z.; Melegh, B. Urinary glycosaminoglycan excretion in healthy and stone-forming children. Pediatr. Nephrol. 1996, 10, 555-558. [CrossRef] [PubMed]

17. Nishio, S.; Abe, Y.; Wakatsuki, A.; Iwata, H.; Ochi, K.; Takeuchi, M.; Matsumoto, A. Matrix glycosaminoglycan in urinary stones. J. Urol. 1985, 134, 503-505. [CrossRef]

18. Lieske, J.C.; Leonard, R.; Toback, F.G. Adhesion of calcium oxalate monohydrate crystals to renal epitelial cells inhibited by specific anions. Am. J. Physiol. Ren. Physiol. 1995, 268, F604-F612. [CrossRef]

19. Verkoelen, C.F.; Romijn, J.C.; Cao, L.C.; Boeve, E.R.; DeBruijn, W.C.; Schroder, F.H. Crystall-cell interaction inhibition by polysaccharides. J. Urol. 1996, 155, 749-752. [CrossRef]

20. Turudic, D.; Batinic, D.; Golubic, A.T.; Lovric, M.; Milosevic, D. Calcium oxalate urolithiasis in children: Urinary promoters/inhibitors and role of their ratios. Eur. J. Pediatr. 2016, 175, 1959-1965. [CrossRef]

21. Milosevic, D.; Rinat, C.; Batinic, D.; Frishberg, Y. Genetic analysis-a diagnostic tool for primary hyperoxaluria type I. Pediatr. Nephrol. 2002, 17, 896-898. [CrossRef] [PubMed]

22. Belostotsky, R.; Seboun, E.; Idelson, G.H.; Milliner, D.S.; Becker-Cohen, R.; Rinat, C.; Monico, C.G.; Feinstein, S.; Ben-Shalom, E.; Magen, D.; et al. Mutations in DHPSL are responsible for primary hyperoxaluria type III. Am. J. Hum. Genet. 2010, 87, 392-399. [CrossRef] [PubMed]

23. Belostotsky, R.; Pitt, J.J.; Frishberg, Y. Primary hyperoxaluria type III-a model for studying perturbations in glyoxylate metabolism. J. Mol. Med. 2012, 90, 1497-1504. [CrossRef] [PubMed]

24. Hoppe, B.; Kemper, M.J. Diagnostic examination of the child with urolithiasis or nephrocalcinosis. Pediatr. Nephrol. 2010, 25, 403-413. [CrossRef] 
25. Ellison, J.S.; Kaufman, S.R.; Kraft, K.H.; Wolf, J.S., Jr.; Hollenbeck, B.K.; Hollingsworth, J.M. Underuse of 24-hour urine collection among children with incident urinary stones: A quality-of-care concern? Urology 2014, 84, 457-461. [CrossRef] [PubMed]

26. Milosević, D.; Batinić, D.; Blau, N.; Konjevoda, P.; Stambuk, N.; Votava-Raić, A.; Barbarić, V.; Fumić, K.; Rumenjak, V.; StavljenićRukavina, A.; et al. Determination of urine saturation with computer program EQUIL 2 as a method for estimation of the risk of urolithiasis. J. Chem. Inf. Comput. Sci. 1998, 38, 646-650. [CrossRef]

27. Milosević, D.; Batinić, D.; Konjevoda, P.; Blau, N.; Stambuk, N.; Nizić, L.; Vrljicak, K.; Batinić, D. Analysis of calcium, oxalate, and citrate interaction in idiopathic calcium urolithiasis in children. J. Chem. Inf. Comput. Sci. 2003, 43, 1844-1847. [CrossRef]

28. Motulsky, H. Intuitive Biostatistics; Oxford University Press: Oxford, UK, 1995.

29. Zelterman, D. Applied Linear Models with SAS; Cambridge University Press: Cambridge, UK, 2010.

30. StatSoft, Inc. STATISTICA (Data Analysis Software System), Version 8.0. 2007. Available online: www.statsoft.com (accessed on 26 November 2013).

31. Graph-Pad Software, San Diego, CA, USA. Available online: http:/ / www.graphpad.com (accessed on 26 November 2013).

32. Witten, I.H.; Frank, E.; Hall, M.A. Data Mining: Practical Machine Learning Tools and Techniques, 3rd ed.; Morgan Kaufmann: Amsterdam, The Netherlands, 2011.

33. Brix, N.; Ernst, A.; Lauridsen, L.L.B.; Parner, E.; Støvring, H.; Olsen, J.; Henriksen, T.B.; Ramlau-Hansen, C.H. Timing of puberty in boys and girls: A population-based study. Paediatr. Perinat. Epidemiol. 2019, 33, 70-78. [CrossRef]

34. Barr, D.B.; Wilder, L.C.; Caudill, S.P.; Gonzalez, A.J.; Needham, L.L.; Pirkle, J.L. Urinary creatinine concentrations in the U.S population: Implications for urinary biologic monitoring measurements. Environ. Health Perspect. 2005, 113, 192-200. [CrossRef]

35. Remer, T.; Neubert, A.; Maser-Gluth, C. Anthropometry-based reference values for $24-\mathrm{h}$ urinary creatinine excretion during growth and their use in endocrine and nutritional research. Am. J. Clin. Nutr. 2002, 75, 561-569. [CrossRef]

36. 36 Batinić, D.; Milosević, D.; Blau, N.; Konjevoda, P.; Stambuk, N.; Barbarić, V.; Subat-Dezulović, M.; Votava-Raić, A.; Nizić, L.; Vrljicak, K. Value of the stone promoters/inhibitors ratios in the estimation of the risk of urolithiasis. J. Chem. Comput. Sci. 2000, 40, 607-610. [CrossRef]

37. Milošević, D.; Batinić, D.; Turudić, D.; Batinić, D.; Topalović-Grković, M.; Gradiški, I.P. Demographic characteristics and metabolic risk factors in Croatian children with urolithiasis. Eur. J. Pediatr. 2014, 173, 353-359. [CrossRef]

38. Kirejczyk, J.K.; Porowski, T.; Konstantynowicz, J.; Kozerska, A.; Nazarkiewicz, A.; Hoppe, B.; Wasilewska, A. Urinary citrate excretion in healthy children depends on age and gender. Pediatr. Nephrol. 2014, 29, 1575-1582. [CrossRef]

39. Cambraeri, G.M.; Kovacevic, L.; Bayne, A.P.; Giel, D.; Corbett, S.; Schurtz, E.; Sukhu, T.; Chiang, G. National multi-institutional cooperative on urolithiasis in children: Age is a significant predictor of urine abnormalities. J. Pediatr. Urol. 2015, 11, 218-223. [CrossRef] [PubMed]

40. Ohana, E.; Shcheynikov, N.; Moe, O.W.; Muallem, S. SLC2A6 and NaDC-1 transporters interact to regulate oxalate and citrate homeostasis. J. Am. Soc. Nephrol. 2013, 24, 1617-1626. [CrossRef] [PubMed]

41. Walker, R.W.; Zhang, S.; Coleman-Barnett, J.A.; Hamm, L.L.; Hering-Smith, K.S. Calcium receptor signaling and citrate transport. Urolithiasis 2018, 46, 409-418. [CrossRef] [PubMed]

42. Michelacci, Y.M.; Boim, M.A.; Bergamaschi, C.T.; Rovigatti, R.M.; Schor, N. Possible role for chondroitin sulfate in urolithiasis: In vivo studies in an experimental model. Clin. Chim. Acta 1992, 208, 1-8. [CrossRef]

43. Akinci, M.; Esen, T.; Kocak, T.; Ozsoy, C.; Tellaloglu, S. Role of inhibitor deficiency in urolithiasis. I. Rationale of urinary magnesium, citrate, pyrophosphate and glycosaminoglycan determinations. Eur. Urol. 1991, 19, 240-243. [CrossRef] [PubMed]

44. Michelacci, Y.M.; Glashan, R.Q.; Schor, N. Urinary excretion of glycosaminoglycans in normal and stone forming subjects. Kidney Int. 1989, 36, 1022-1028. [CrossRef]

45. Sas, D.J. An update on the changing epidemiology and metabolic risk factors in pediatric kidney stone disease. Clin. J. Am. Soc. Nephrol. 2011, 6, 2062-2068. [CrossRef]

46. Dissayabutra, T.; Kalpongnukul, N.; Chindaphan, K.; Srisa-art, M.; Ungjaroenwathana, W.; Kaewwongse, M.; Iampenkha, K.; Tosukhowon, P. Urinary sulfated glycosaminoglycan insufficiency and chondroitin sulfate supplement in urolithiasis. PLoS ONE 2019, 14, e0213180. [CrossRef] [PubMed]

47. Poon, N.W.; Gohel, M.D. Urinary glycosaminoglycans and glycoproteins in a calcium oxalate crystallization system. Carbohidr. Res. 2012, 347, 64-68. [CrossRef] [PubMed] 